УАK 351.74:614.8

ББК 67.401.13+68.92

DOI 10.22394/1682-2358-2017-3-61-65

E.A. Busbueva, post-graduate student of the Administrative and Criminal Law Department, Povolzhsky Institute of Management named after P.A. Stolypin, Branch of the Russian Presidential Academy of National Economy and Public Administration

\section{ADMINISTRATIVE AND LEGAL REGULATION OF INTER- REGIONAL LEVEL OF POPULATION PROTECTION FROM NATURAL AND ANTHROPOGENIC THREATS}

The unified state system of prevention and liquidation of emergencies is analyzed. Organizational and legal aspects of emergency services state registration are considered. The necessity of creating a centralized act providing unified conditions and procedure for registration of newly created emergency services is proved.

Key words and word-combinations: population protection from emergencies, emergency services, legal regulation, state registration.
E.A. БуиуеВа, аспирант кафедри административного и уголовного праља Поволжского института утравления имени П.А. Стольтина - филиала Российской академии народного хозяйстьа и государственной службь при Президенте РФ (етаil: elena-091924@mail.ru)

\section{ААМИНИСТРАТИВНО- ПРАВОВОЕ РЕГУ ИИРОВАНИЕ МЕЖРЕГИОНААЬНОГО УРОВНЯ ЗАЩИТЫ НАСЕАЕНИЯ ОТ ПРИРОАНЫХ И ТЕХНОГЕННЫХ УГРОЗ}

Аннотация. Анализируется единая государственная система предупреждения и ликвидации чрезвычайных ситуаций. Рассматриваются организационно-правовые аспекты государственной регистрации аварийно-спасательных служб. Доказывается необходимость создания централизованного акта, предусматривающего единые условия и порядок регистрации вновь создаваемых аварийно-спасательных служб.

Ключевые слова и словосочетания: защита населения от чрезвычайных ситуаций, аварийноспасательные службы, правовое регулирование, государственная регистрация.

$\mathrm{O}$ от совокупности природных, техногенных и иных угроз, явмяющееся центрамьной функцией государства, требует соблюдения иерархичности при реализации широкого спектра мероприятий, направленных на подАержание надмежащей защищенности всех предусмотренных Конституцией РФ 
прав и свобод граждан. В соответствии с территориальным делением России выделяют федеральный, региональный и местный уровни безопасности. Изучение положений Федерального закона от 21 декабря 1994 г. № 68-Ф3 «О защите населения и территорий от чрезвычайных ситуаций природного и техногенного характера» показывает, что существует строгая субординация в определении компетенции федерального џентра, связанной с миквидацией инцидентов, аварий и катастроф (ст. 8-10, 12, 13), органов государственной вцасти субъектов РФ (ч. 1 ст. 11), а также органов муниџипацьного управления (ч. 2 ст. 11). Согласно данному Закону имеется еще один уровень обеспечения безопасности - мокальный (объектовый). Исходя из обязанности юридических миџ осуществяять определенные мероприятия в области защиты граждан от природных и техногенных угроз (ст. 14), некоторые авторы признают его организационно обособленным и, следовательно, самостоятельным в системе обеспечения безопасности [1]

Положение о единой государственной системе предупреждения и миквидации чрезвычайных ситуаций устанавливает системный подход к определению субординации в решении общего спектра вопросов, связанных с защитой насемения [2] . В п. 3 отражкено, что ЕАиная система, состоящая из функциональных и территориальных подсистем, действует на федеральном, мехрегиональном, региональном, муниципальном и объектовом уровнях. Из этого вытекает, что комплекс мер, направленных на предотвращение несчастных случаев, предпомагает существование межрегионального уровня. В п. 5 указанного Положения закреплено, что в пределах соответствующего федерального округа (межрегиональный уровень) функции и задачи по обеспечению координации деятельности федеральных органов исполнительной власти и их взаимодействия с органами государственной власти субъектов РФ, органами местного самоуправления и общественными объединениями в области защиты населения и территорий от чрезвычайных ситуаций осуществцяет в установленном порядке полномочный представитель Президента РФ в федеральном округе.

Н.Г. Жаворонкова считает, что при подобном подходе допускается необоснованное Аробление установценных в законодательстве систем (подсистем) обеспечения безопасности путем создания внесистемных образований. Если следовать могике законодателя, то возможно формирование таких уровней, как межмуниципальный и межобъектовый, а это, в свою очередь, не соответствует конституционным положениям, связанным с территориальным делением Российской Федераџии и вытекающим из них функциональным разделением

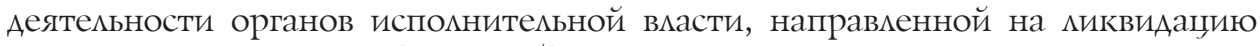
общих и частных угроз [3, с. 105].

Р.Б. Гладких указывает на отсутствие особой группы постоянно Аействующих специализированных органов, которые имеют обособленные и четко очерченные функщии обеспечения безопасности на этом уровне. Здесь в качестве субъектов управцения законодатель обозначиц территориальные органы Министерства Российской Федерации по делам гражАанской обороны, чрезвычайным ситуациям и миквидации последствий стихийных бедствий (региональные центры по делам гражданской обороны, чрезвычайным ситуациям и миквидации последствий стихийных беАствий). В Аанном случае они буАут 
осуществлять свои полномочия искцючительно на начацах координации и взаимного сотрудничества. При этом подобные полномочия территориальные образования МЧС России реализуют в совокупности с Аругими, имеющими прямое действие на подведомственной им территории. Рассматривая координацию в системе обеспечения защиты прав и интересов граждан от совокупности разцичного рода угроз, исследователь отмечает, что она неизменно присуща всем органам, задействованным в рассматриваемой сфере, поэтому не может выступать в качестве характеристики, принципиацьно обособцяющей какую-либо группу органов в системе предупреждения и защиты населения от негативного воздействия природных и техногенных факторов [4, с. 48] .

Таким образом, межрегионамьный уровень безопасности и его обеспечение представцяют собой, по сути, применение на практике усиций и среАств заинтересованных ведомств и организаций субъектов РФ, руководить которыми могут преАставители федерального центра с привцечением дополнительных сил, отсутствующих в регионах. ОАнако совокупность организационных механизмов, применяемых федеральным и региональными органами власти при миквидации чрезвычайных ситуаций как на территории одного субъекта Федерации, так и на приграничных территориях, немьзя признать компонентом, составцяющим основу характеристики межрегионального уровня обеспечения безопасности. С нашей точки зрения, закрепление в Положении о единой государственной системе предупрежкения и миквидации чрезвычайных ситуаций межкрегионального уровня защиты населения от всей совокупности вредоносных факторов не преАставцяется могичным и концептуально обоснованным.

Необходимое спасательным организаџиям основание дмя осуществления действий по спасению граждан и имущества - их государственная регистрация. По словам Ю.А. Тихомирова, она преАставляет собой один из способов воздействия на экономику, «...институт публичной вцасти дмя обеспечения пубцичных интересов и охраны законности на экономическом поле, регулируемый нормами административного и гражданского права» [5, с. 419]. В.А. Юсупов отмечает, что роль государственной регистрации «главным образом состоит в том, чтобы удостоверить юридические факты или их системы. Следовательно, акт регистрации явмяется решением компетентного государственного органа, указывающим на юридическое состояние субъекта общественных отношений» [6, с. 63] .

При рассмотрении правовых аспектов государственной регистрации аварийно-спасательных служб речь идет о юридическом закреплении организационно-правовой формы создаваемых организаций, осуществляющих деятельность в сфере Аиквидации послеАствий чрезвычайных ситуаций и стихийных беАствий. Низовые объекты, входящие в систему МЧС России, являются территориальными подразделениями этого министерства и не нужАаются в Аополнительной фиксации своего статуса.

Поскоцьку анацизируемые объекты составцяют основу сиц постоянной готовности и, как отмечалось, осуществляют реализацию спещифических целей и задач, можно считать их некоммерческими организациями. Вместе с тем формально Федеральные законы «О государственной регистрации юридических миџ и индивидуальных предпринимателей» и «Об аварийно-спасательных службах и статусе спасателей» не содержат преград к регистрации гражда- 
нина в качестве индивидуального предпринимателя, который планирует осуществцять спасательную, миквидаџионную деятельность в этой сфере.

Исходя из специфики функщионирования аварийно-спасательных организаций и учреждений, их места в ЕАиной государственной системе предупреждения и Аиквидации ЧС, обусловленного специфическими связями и способами воздействия на общественные отношения, полностью их деятельность некоммерческой не явмяется. Например, ГУ «Московская областная противопожарно-спасательная служба» вправе оказывать физическим и юридическим мицам на возмездной основе следующие услуги: осуществление работ, в том числе профилактических, по обслуживанию объектов, территорий, а такжке водоемов Московской области на договорной основе; распространение пиротехнических изделий IV и V классов в соответствии с государственным стандартом, в том числе организация проведения фейерверков с использованием пиротехнических изделий; сбор, использование, обезвреживание, транспортировка, размещение опасных отходов, миквидация ( окализация) на море, внутренних акваториях и территориях разцивов нефти, нефтепродуктов, химических и Аругих экологически опасных веществ; образовательная и издательская деятельность в области защиты населения и территорий от чрезвычайных ситуаций; разведение, подготовка и специальное обучение собак, работы по обеспечению безопасности в местах отдыха населения на пляжах и акваториях Московской области по предупреждению несчастных случаев и спасению утопающих на договорной основе [7].

В соответствии со ст. 11 Федерального закона от 22 августа 1995 г. № 151Ф3 «Об аварийно-спасательных служббах и статусе спасателей» профессиональные аварийно-спасательные службы и профессиональные аварийно-спасательные формирования могут осуществлять свою деятельность по обслуживанию объектов и территорий на договорной основе. В ч. 4 указанной статьи содержится специальная оговорка, согласно которой среАства, полученные АСФ, созданными федеральными органами исполнительной вцасти, органами исполнительной власти субъектов РФ и органами местного самоуправления, от выполнения Аоговоров по обслужкиванию объектов и территорий после уплаты налогов и сборов, предусмотренных законодательством Российской Федерации, подмежат зачислению в Аоход соответствующего бюджета бюджетной системы Российской Федераџии [8] .

Чтобы осуществлять профессиональную деятельность в полном объеме, анамизируемые объекты системы государственного управления ЧС подвергаются Аополнительной регистрационной проџедуре. Федеральный закон № 151-Ф3 в ст. 10 устанавливает, что все аварийно-спасательные службы и аварийно-спасательные формирования подлежат обязательной регистрации, которую осуществцяют федеральный орган исполнительной власти, специально уполномоченный на решение задач в области защиты населения и территорий от чрезвычайных ситуаций, органы исполнительной власти субъектов РФ и органы местного самоуправления, специально уполномоченные на решение задач в области защиты населения и территорий от чрезвычайных ситуаций, в соответствии со своими полномочиями. ОАнако содержание и порядок практической реализаџии этого положения не раскрывается. Специальные акты МЧС России, регламентирующие процедурные аспекты этого вида регистрации, отсутствуют. ЕАинственная норма, сопоставимая с требованиями ст. 10 Федерального закона «Об аварий- 
но-спасательных служббах и статусе спасателей», обязывает ГУ МЧС России по субъекту Федераџии организовывать учет аттестованных аварийно-спасательных служб, пожарных, пожарно-спасательных, поисково-спасательных и аварийноспасательных формирований, общественных объединений, имеющих уставные задачи по проведению аварийно-спасательных работ и тушению пожкаров и Аействующих на территории субъекта РФ (п. 10 Положения).

Реацизация на практике положкений ст. 10 указанного Закона оставцяет нерешенными ряд вопросов. Аопустим, общественное объединение, имеющее юридический аАрес на территории муниџипального образования, приняло решение о создании аварийно-спасательного формирования, деятельность которого можкет осуществляться как в пределах субъекта Федерации, так и вне их. Законодательство не регламентирует, какие органы должны его зарегистрировать: местные органы власти, органы управления ГО и ЧС региона, территориальный орган МЧС России или же каждый из них. Не ясна и форма этой процедуры - разрешительная, явочная или уведомительная. В Федеральном законе от 8 августа 2001 г. № 129-ФЗ «О государственной регистрации юридических миџ и инАивиАуаАьных предпринимателей» определен порядок государственной регистрации юридических миџ и индивидуальных предпринимателей: а именно срок ее осуществления, порядок представления необходимых документов, принятие решения, выдача Аокументов, подтверждающих факт государственной регистраџии по форме, опреАеленной уполномоченным Правительством РФ федеральным органом исполнительной власти и т.А. Федеральный закон «Об аварийно-спасательных служббах и статусе спасателей» и иные нормативные акты никак не регламентируют данные аспекты. Кроме того, указанный Закон не устанавливает последствий отказа в регистрации АСФ в отмеченных органах и не опредемяет особенностей их дальнейшей деятельности при отриџательном решении компетентных Аолжностных миц. Решить эти проблемы мог бы централизованный акт, принятый на уровне МЧС России или Правительства РФ, который предусматривал бы единые условия и порядок регистрации вновь создаваемых аварийно-спасательных служкб.

\section{Библиографический список}

1. Галицкая Н.В. Административно-правовые элементы (компоненты) обеспечения национальной безопасности в России // Вестник Саратовской государственной юридической академии. 2012. № 4 (87) С. 64-68.

2. О единой государственной системе предупреждения и ликвидации чрезвычайных ситуаций: постановление Правительства РФ от 30 дек. 2003 г. № 794 // СЗ РФ. 2004. № 2. Ст. 121.

3. Жаворонкова Н.Г. Конституционные проблемы обеспечения безопасности при чрезвычайных ситуациях природного и техногенного характера // Право и государство: теория и практика. 2007. № 3. С. 103-110.

4. Гладких Р.Б. Обеспечение безопасности предпринимательской деятельности в системе мер, обеспечивающих экономическую безопасность государства // Юридический мир. 2006. № 10 . С. $40-44$.

5. Тихомиров Ю.А. Курс административного права и процесса. М., 1998.

6. Юсупов В.А. Правоприменительная деятельность органов управления. М., 1979.

7. Распоряжение министерства имущественных отношений Московской области от 20 нояб. 2007 г. № 1585 [Электронный ресурс]. Доступ из СПС «КонсультантПлюс».

8. Седнев B.A. Организация защиты населения и территорий от чрезвычайных ситуаций: учебник. 3-е изд., перераб. и доп. М., 2014. 